\title{
FRENCH LANGUAGE TEACHING AND ONLINE MULTIMEDIA RESOURCES
}

\author{
Anna Antropovskaya \\ Teaching Assistant, Law Institute, RUDN University, RUSSIA, aniaantr@gmail.com
}

\begin{abstract}
This study aims at identifying useful Internet sources in order to apply them for the purposes of teaching French language. Currently, within the COVID-19 pandemic, the major part of classes is conducted online. Therefore, it is extremely important to use Internet resources in order to make online lessons more interesting, attractive and fruitful. The investigation shows that there are plenty of tools that help to enhance online classes. In order to reveal the most appropriate Internet sources, it is necessary to follow the comparative approach. The use of materials depends on the age and level of students. However, there are some sites which are suitable for everyone. The analysis of a huge number of websites makes it possible to identify their advantages and disadvantages. Many multimedia features have emerged in recent years. It is important not only to teach students French, but also to give them an opportunity to search for the necessary information on the Internet by themselves. The language is an integral part of culture. Therefore, it is important to know more about French history, culture and traditions. Sometimes it may be difficult for students to study it. Meanwhile, Internet resources help to make lessons more dynamic and exciting. The results indicate that nowadays there are various appropriate Internet resources that may be used in order to increase involvement of students in all types of online activities. This research focuses on a limited number of the articles; hence it is impossible to state that only these websites are suitable for online classes. Further research is needed to analyze and find out other tools that can be useful for teaching French online.
\end{abstract}

Keywords: French language, online classes, Internet resources.

\section{INTRODUCTION}

The Third Millennium has confirmed the potential of university-based multimodal and multilingual communication for students' sustainable development within diverse societal contexts, including traditional learning and emergency-caused settings (Atabekova, 2020, Gazzola et al., 2020, Kuteeva et al., 2020).

Contemporary schools in applied research and didactics of language learning/teaching agree that audiovisual sources (news, cartoons, and films) should be viewed as valuable instruments for authentic language learning (Bahrani, Sim, 2012).

Scholars agree that the above tools contribute to learning quality and student motivation development (Sulihin et al., 2020). Researchers also underline that the use of visual aids help in foreign language help students to structure their system of knowledge in a foreign language (Pateşan et al., 2018).

The use of audiovisual materials for teaching has become more accessible with the development of new technologies (Dukhanina, 2013, Otto et al., 2017). The integrated study of a foreign language involves teaching of culture and history of the country. New technologies allow the teaching community to integrate multimodal resources into the teaching process (Shadiev, Yang, 2020).

In France, cinematography is one of the most important and widespread kind of art, therefore acquaintance with it, to one degree or another, should be integrated into the educational process. 
Nowadays there are a huge number of sites that can be useful in studying French cinematograph. The Cinémathèque Française is certainly the most important resource. But it is also important to consider the possibilities that other sites provide. A huge number of films can be found on the website of the Institut Français. They are divided into categories. It helps to figure out materials on topics of interest. An equally rich collection of films can be found on the website TV5MONDE. This collection benefits from a large number of documentary films.

Cinematography originated in France. It has become a matter of national pride. Many French actors have become world famous, film directors continue to influence the development of the film industry.

The authority of France emphasizes the importance of cinematography and assists both in the development of this kind of art and in its dissemination. In recent years, France has paid particular attention to public diplomacy. Cinematography has contributed to projecting a positive image of the country abroad and the spread of the French language.

The development of relations between Russia and France in the field of culture, as well as the spread of modern technologies, make acquaintance with French cinema more accessible. Currently, there are two major ways of art appreciation. Firstly, students of Moscow higher educational institutions have an opportunity to attend the French Institute, opened in 2011, where film festivals and meetings with prominent artists are regularly held. Secondly, acquaintance with French cinema can be integrated into the educational process.

The theoretical background of the study integrates the research data of international scholars (see citations across the text) and takes into account particular publications of modern Russian scholars (Kudinova, 2018, Sidakova, 2016) on the use of audiovisual material in foreign languages teaching.

The empirical observations and conclusions rested on the data from the site of the Cinémathèque Française.

The purpose of the research is to consider the ways of using audiovisual material in teaching French. To achieve this goal, the following tasks were set: to analyze the ways of integrating familiarity with French cinema into the educational process, consider the opportunities offered by the use of authentic audiovisual materials and identify possible types of work using the resources of French cinema.

The relevance of the study is connected with the need to consider ways how to use authentic material for teaching French, especially in the context of the coronavirus pandemic, since the use of multimedia resources within distance learning attracts and motivates students, and does not require any additional technologies.

\section{METHODOLOGY}

The study combined desk research and empirical investigation of resources. The analysis compared traditional approaches (Champoux, 1999) and new angles of consideration of audiovisual materials potential for approaches to foreign language teaching/learning, including the focus on pragmatics-oriented (Peñarroja, 2020), learner-centered (Philominraj et al., 2017), and functional behavior approach to foreign language acquisition (Atabekova 2015a).

Textual and audio-visual materials posted on the website of the Cinémathèque Française, TV5MONDE and the French Institute were used in this study.

The background of the empirical analysis was the method of comparative analysis, because it is necessary to identify the most suitable films for studying the French language, history and culture. The analysis of specific tasks that can be set in the framework of learning a foreign language was used for a detailed study of both possible types of activities related both to the use of authentic audiovisual materials and for the choice of the most suitable films for these purposes.

\section{RESULTS}

The use of authentic audiovisual materials, namely feature films, offers many opportunities and contributes to the successful study of a foreign language. Currently, there is an increasingly active use of such materials, that could be explained by the development of technological capabilities and the emergence of an increasing number of methodological developments related to this type of activity.

The development of the ability to perceive speech is an integral part of learning a foreign language. Listening helps to improve pronunciation and get used to the sound of French speech. A film "La Course à l'échalote" 
can be used in order to consider how Pierre Richard articulates consonants, as well as the difference between the pronunciation of open and closed vowels.

Films provide an opportunity to know more about the culture of France, the lifestyle and mentality. The comedy "Qu'est-ce qu'on a fait au Bon Dieu?" addresses the problem of multiculturalism. Undoubtedly, this issue cannot be fully disclosed in one film, but, nevertheless, it gives an opportunity to find out the main idea and to analyse a situation in France. Moreover, the film was highly appreciated in France. In particular, the newspaper "Figaro" published an article highlighting the merits of this film.

Another advantage of using feature films in French language teaching is an opportunity to learn more about particular periods of history, to understand the mores of the era and get acquainted with daily life. For example, the film "La Reine Margot" is about the religious war in France, in particular about St. Bartholomew's Night.

Feature films can serve as a source of idiomatic, fixed expressions and catch-phrases. For example, in the film "Les Choristes" music teacher Clément Mathieu uses the expression "se tenir à carreau", which can be translated as "keep it together".

Furthermore, watching movies can evoke an emotional response and serve as an additional motivation for learning French. An interest in the cinematograph may encourage French language students to attend film clubs and they would be able to ameliorate their knowledge of foreign languages. The cultural aspect is extremely important therefore acquaintance with French cinema can facilitate the communication process with native speakers.

It should be noted that the importance of studying a foreign language in higher educational institutions comes down not only to vocabulary and grammar, but also to understanding the culture and mentality of the country. Higher education presupposes an integrated approach and provides an opportunity in addition to knowledge that can be further applied in practice within the studied specialty to broaden horizons and become to some extent an expert in various fields.

\section{DISCUSSION}

Within the framework of this study, the merits of the use of authentic audiovisual materials in teaching French were analyzed, and practical recommendations were given on the use of films for specific purposes.

Indeed, the ways and advantages of using cinema in teaching of foreign languages have already been described in previous researches, however the topic is not sufficiently developed, it is necessary to continue research and analyze the ways of using audiovisual materials for specific purposes. The study correlates with previous research and adds new aspects.

The scientific novelty of this study is connected with the fact that not only the possibilities of using feature films for teaching French are considered, but also specific examples are provided. It demonstrates how it can be used. The study focuses on aspects should be touched upon in the framework of learning a foreign language, resorting to the use of multimedia materials in the educational process.

The practical use of authentic audiovisual materials is related to the development of technological capabilities and the need to use multimedia resources in distance education. The knowledge gained through the use of such resources is especially important for the study of the linguistic and cultural aspect.

There are various ways how to implement feature films. Firstly, it can be considered as materials for listening. After watching some fragments of the film students can answer questions about the content, memorize dialogues or scenes in order to remember new words and phonetic features. Moreover, it is useful to retell the plot. Secondly, after watching a feature film discussions and debates could be organized. It would help to ameliorate students' communication skills. It is extremely important to develop the ability to express position.

In addition, films provide an opportunity to improve grammar and vocabulary. For an in-depth study of the French language students can translate subtitles and compare plots of books and films. It should be noted that translation of subtitles develops analytical skills in general and is a popular type of translation.

The above empirical observations go in line with the findings of researchers with regard to respective material use in English (Montero Perez et al., 2018), confirm that audiovisual items from films can contribute to learners' progress even at the elementary level (Bimo, Rensi, 2020), and with regard to genredifferentiated materials (Ruck, 2020). 
Further, the study confirms that the film materials in French can be selected to organize theme-focused sections that can be structured into audiovisual corpus with its further use for sound speech recognition and production in a native speaker's way. Such and experience with regard to other languages has been described in earlier studies (Czyzewski et al., 2017). Moreover, cloud-based accumulation of resources that comprise theme-focused sections of the films can help students to overcome their knowledge divide, as it was mentioned with reference to sources in English in earlier studies (Atabekova, 2015b).

With regard to the emergency settings due to pandemics (see COVID 19 as an example) or other social troubles that put limits to the students' international mobility programs, the use of films is a valuable tool to foster internationalization at home in general (Atabekova, 2016), and for the French language learning, in particular.

\section{CONCLUSION}

The research considers the possibilities of using authentic audiovisual materials in the educational process. The results of the study lead to the following conclusions.

The use of films for teaching foreign languages has a number of positive aspects. Currently, there is an increase in interaction between Russia and France therefore there is a need to get acquainted with its culture. The role of cinema in France should also be highlighted. Paris is actively conducting various events and it helps to know more about the history, culture, traditions and language of the country. Russia and France closely interact in the field of cinematograph, there is a necessity to pay special attention to this kind of art in the framework of language teaching. The countries have rich experience of cooperation in the creation of joint films and cultural exchange, they maintain active cooperation within the framework of the Cannes and Moscow film festivals.

Practical advice on the use of cultural objects in general and feature films in particular when studying a foreign language helps to identify new opportunities for both teachers and students. Language is an important element of culture, therefore, studying the art of another country can become an impetus for learning the language, students and teachers have an opportunity to use some elements of the culture. Moreover, the teacher can involve students in learning the language by watching films in line with students' interests (for example, history, politics or religion) and different topics (such as multiculturalism, interpersonal relations and national mentality).

The article has a number of limitations. Firstly, it considers only the background points of audiovisual resources use, it does not tend to focus on the specific areas of feature films integration in foreign languages didactics. Secondly, the study does not describe all types of tasks connected with language teaching/learning activities. Further research involves a more detailed analysis of materials for specific linguistic disciplines, as well as a comparison of the possibilities of multimedia resources use in other foreign languages learning process.

\section{REFERENCE LIST}

Atabekova, A. (2020). University discourse to foster youth's sustainability in society amidst COVID19: International and Russian Features. Sustainability, 12(18), 7336.

Atabekova, A. (2015a). Functional Behavior Approach to Evaluate Patterns of Foreign Language Acquisition: Using Web 3.0 Tools. In: 7th International Conference on Education and New Learning Technologies (EDULEARN 15). July 06-08, Barcelona, Spain, 6235-6239.

Atabekova, A. (2015b). Foreign Language and Mediation Skills Training in the Cloud to Overcome Knowledge Divide. In: 9th International Technology, Education and Development Conference (INTED 15), March 02-04, Madrid, Spain, 6482-6485.

Atabekova, A. (2016). Fostering Internationalization at Home through Non-formal Learning. In:8th International Conference on Education and New Learning Technologies (EDULEARN 16). July, 04-06, Barcelona, SPAIN, pp.2638-2642.

Bahrani, T., Sim, T. S. (2012). Audiovisual News, Cartoons, and Films as Sources of Authentic Language Input and Language Proficiency Enhancement. Turkish Online Journal of Educational TechnologyTOJET, 11(4), 56-64. 
Bimo, D. S., \& Rensi, M. Y. (2020, May). Audio visual media versus games media on mastery of English vocabulary for elementary school student. In Emerging Perspectives and Trends in Innovative Technology for Quality Education 4.0: Proceedings of the 1st International Conference on Innovation in Education and Pedagogy (ICIEP 2019), October 5, 2019, Jakarta, Indonesia (p. 141). Routledge.

Champoux, J.E. (1999). Film as a Teaching Resource. Journal of Management Inquiry, 8 (2).

Czyzewski, A., Kostek, B., Bratoszewski, P., Kotus, J., Szykulski, M. (2017). An audio-visual corpus for multimodal automatic speech recognition. Journal of Intelligent Information Systems, 49(2), 167-192.

Dukhanina, N.M. (2013). Media educational approach to teaching foreign languages. In:Media Education 2013: Collection of the International Forum of Conferences.

Gazzola, M., Templin, T., \& McEntee-Atalianis, L. J. (2020). Measuring diversity in multilingual communication. Social Indicators Research, 147(2), 545-566.

Kudinova, V.A. (2018). Italian language and cinema: questions of linguistics and didactics Language. Culture. Transfer. Communication.

Kuteeva, M., Kaufhold, K., \& Hynninen, N. (2020). Introduction: Language Perceptions and Practices in Multilingual Universities. In Language Perceptions and Practices in Multilingual Universities (pp. 1-24). Palgrave Macmillan, Cham.

Montero Perez, M., Peters, E., \& Desmet, P. (2018). Vocabulary learning through viewing video: the effect of two enhancement techniques. Computer Assisted Language Learning, 31(1-2), 1-26.

Otto, S. E., Chapelle, C., Sauro, S. (2017). From past to present: A hundred years of technology for L2 learning. The handbook of technology and second language teaching and learning, 10-25.

Pateşan, M., Balagiu, A., \& Alibec, C. (2018, June). Visual aids in language education. In: International Conference Knowledge-Based Organization (Vol. 24, No. 2, pp. 356-361). Sciendo.

Peñarroja, M. R. (2020). Pragmatics: Why Use Audiovisual Input in Second and Foreing Language Learning Contexts?. Revista Docência e Cibercultura, 4(3), 161-178.

Philominraj, A., Jeyabalan, D., Vidal-Silva, C. (2017). Visual Learning: A Learner Centered Approach to Enhance English Language Teaching. English Language Teaching, 10(3), 54-62.

Ruck, J. (2020). Elementary-level learners' engagement with multimodal resources in two audio-visual genres. The Language Learning Journal, 1-16.

Shadiev, R., \& Yang, M. (2020). Review of studies on technology-enhanced language learning and teaching. Sustainability, 12(2), 524.

Sidakova N.V. (2016). Authentic audiovisual material as a didactic method in teaching French to students of non-linguistic specialties. Baltic Humanitarian Journal.

Sulihin, S., Asbar, A., \& Elihami, E. (2020). Developing of Instructional Video Media to Improve Learning Quality and Student Motivation. Edumaspul: Jurnal Pendidikan, 4(2), 51-55. 